\title{
THE SCIENTIFIC AND MANAGERIAL IDEAS OF ACADEMICIAN GHEORGHE DUCA ARE REALIZED SUCCESSFULLY BECAUSE THESE ARE BASED ON KNOWLEDGE
}

The Chemistry Journal of Moldova. General, Industrial and Ecological Chemistry is an editorial-scientific work of national and international value. The journal is indexed in various prestigious international databases.

The idea to found this journal came from academician Gheorghe Duca 16 years ago, while he held the position of President of the Academy of Sciences of Moldova. For 16 years, the journal has been published twice a year with the most important scientific results obtained by chemical researchers not only in the Republic of Moldova, but in various scientific centers around the world, as well.

After graduating the Faculty of Chemistry of the State University of Moldova in 1974, the young graduate Gheorghe Duca is employed in the field of Physical Chemistry of the Faculty of Chemistry. After having analysed the state of the environment in the Republic of Moldova and around the world, the researcher Gheorghe Duca concludes that the components of environment, air, water, and soil are polluted rapidly due to the discharge into the environment of toxic substances from industrial, agricultural and communal enterprises. In order to save the environment from pollution, the young scientist Gheorghe Duca presents the idea of founding a scientific school in the field of ecological chemistry, a field which may be defined, according to the founder, as the science which studies the processes that determine the composition and chemical properties of the environment, adequate to the biological value of the habitat. This required multiple fundamental ideas with practical application to guide dozens of doctoral and postdoctoral students to conduct research in the field of ecological chemistry. Within the scientific school under the leadership of academician Gheorghe Duca were defended 5 doctoral theses and $30 \mathrm{PhD}$ theses in chemical sciences.

During the years, academician Gheorghe Duca together with his students and colleagues developed the theory of the redox phenomenon in the environment, elucidated the mechanisms of oxidation and reduction of components in the process of forming the quality of aquatic systems, (C) Chemistry Journal of Moldova

CC-BY 4.0 License

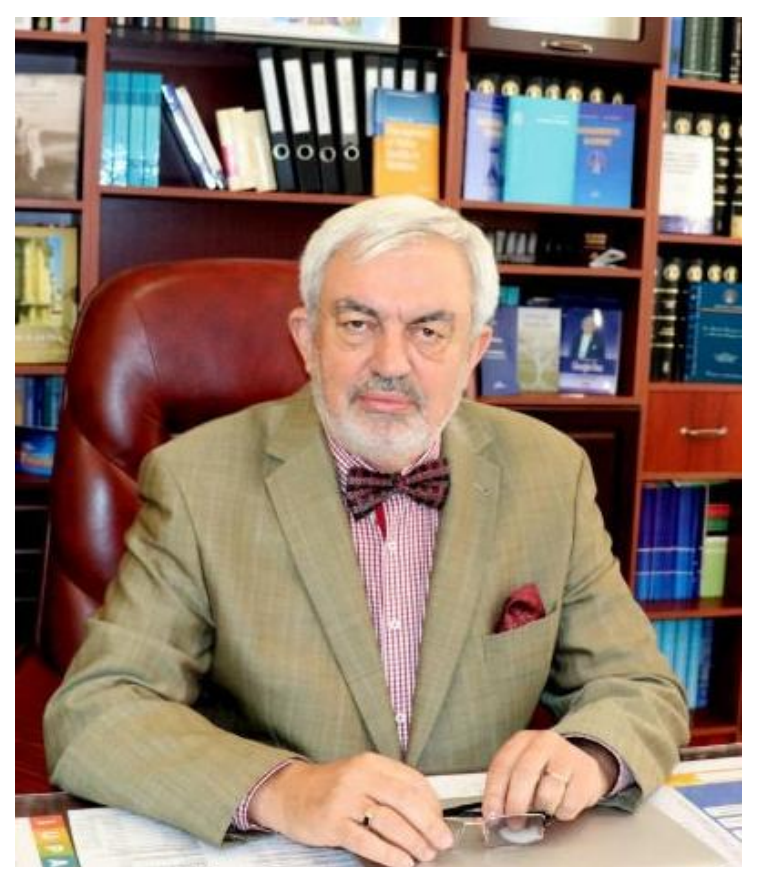

Academician Gheorghe Duca (2021)

as well as oenological products. They developed: technologies for physical-chemical and biochemical treatment of wastewater; waste recovery; technologies of obtaining medicinal and cosmetic substances; to reduce atmospheric pollutants; methods for estimating the chemical risk in the occurrence of lung and gastrointestinal cancer; new processes for obtaining biologically active substances; ecological audit; ecological education, etc.

The results of the scientific research of the world-class scientist Gheorghe Duca speak for themselves. The total number of scientific publications is over 1800 , of which: scientific articles - 577, scientific monographs and textbooks - 94, presentations at international and national scientific conferences - 433, patents and inventions - 166, many of which were awarded special prizes, gold and silver medals at the International Invention Shows in Chisinau, Brussels, Geneva, Budapest, Iasi, Moscow, London, Sofia, Beijing, Seoul. The scientist Gheorghe Duca published more than 520 times in the republican press, gave interviews to various radio and TV stations, disseminating the results of 
scientific research in an accessible form for the interested audience.

Scientific, teaching and managerial contribution of academician Gheorghe Duca was appreciated at home as well as abroad, being awarded many honorific titles, such as: Honourary Order "ProScientia et Innovatio" for outstanding contribution to the progress of science, Romanian Inventors Forum, Romania (2019); Gold Medal "For Excellence in Innovations and Creativity", INVENT-INVEST2018, Romanian Academy (2018); Gold Medal "The centenary of the Great Union 1918-2018", Great contributors to Unification: Ferdinand 1 (1914-1927), Alexandru Ioan Cuza (1869-1866), Mihai Viteazul (1593-1601), Romanian Sky and Land (2018); European Innovation Award, Diploma of Commander, European Commission, Belgium (2018); Medal "Academic Merit", Romania, (2018); Medal "Paul Bran" for the academic management, Romania (2018); Medal of 25th Anniversary of International Association of Academies of Sciences, Belarus (2018); European Innovation Award with Diploma of Commander, The High Commission of the Invention Award, Brussels, Belgium (2018); ICMSEM Runners up Prize for Scientific Papers, Japan (2017); Medal "Scientific Merit, 1st Grade", Academy of Sciences of Moldova (2017); Award of the Parliamentary Assembly of the Black Sea Economic Cooperation Organization (BSEC) (2016); Order "The crown of Romania" with the rank of Commander (2015); Medals "Henri Coanda" and Mihai Eminescu, Romania (2014); Award for outstanding achievements in the field of EIECO Black Sea (2013); Award of The Romanian Academy (2012); Order of the Republic (2011); Gold Medal "EUROINVENT", Brussels (2011); National Award GALEX (2011); Silver Medal of the Association of Innovators of China (2010); International Socrates Award, Oxford, UK (2009); Gold Medals "I.P. Pavlov", "N.S. Kurnakov" and "B.I. Blinikov", Russian
Federation (2004, 2007, 2008); Order "Labour Glory" (2007); Gold Medal "for Eminent Services to the cause of progress", Brussels (2005); "The Cross of Commander of the Order of Honour", Poland (2004); Knight of the Order for Inventions of the Kingdom of Belgium (2003); Medal "Dimitrie Cantemir" (2002); State Prize in Science and Technology (1998, 2004); Emeritus scientist (1996).

For more than 30 years academician Gheorghe Duca materialized the idea that international meetings of scientists at various conferences, symposia, scientific congresses is a beneficial thing for science. These scientific events offer the opportunity to find out, in just 2-3 days, the scientific news that have accumulated decades of research and innovation at colleagues from different scientific centers around the world. These events create real opportunities to network with colleagues from abroad and organize international bilateral or plurilateral collaborations in European and global research and development projects. So far, academician Gheorghe Duca successfully organized 6 editions of the International Conference "Ecological and Environmental Chemistry" (EEC). On March 3-4, 2022, the Society of Chemistry of the Republic of Moldova, the Institute of Chemistry, the Faculty of Chemistry and Chemical Technology of the State University of Moldova intends to organize the VII International Conference EEC-2022, dedicated to the $70^{\text {th }}$ anniversary from the birthday of the illustrious scientist Gheorghe Duca. The current jubilee is an occasion to pay a beautiful homage and gratitude to this tireless researcher and organizer of science, whose activity is a worthy example to follow of serving the nation and the land.

Thus, dear readers of the Chemistry Journal of Moldova, we are looking forward seeing you in Chisinau with scientific communications at the $\mathrm{VII}^{\text {th }}$ International Conference EEC-2022.

Academician, dr. habilitate Tudor LUPASCU Head of Centre of Ecological and Environmental Protection, Institute of Chemistry

Dr. habilitate Aculina ARICU Director of the Institute of Chemistry 